\title{
System design principles in customer-driven manufacturing
}

\author{
Klaus-Dieter Thoben \\ Bremen Institute of Industrial Technology and Applied Work Science (BIBA) at the University \\ of Bremen, Hochschulring 20, 28359 Bremen, Germany. \\ Email: tho@biba.uni-bremen.de
}

\begin{abstract}
Today focusing on the individual needs of the customer has gained broad attention in industry. Accordingly, for many branches the concept of Mass customisation (MC) has been identified as a competitive strategy. Theoretical, technical as well as managerial aspects have been studied and are still studied aiming at a better understanding of this new paradigm. At the same time, there is a long tradition in various branches in designing and manufacturing customer specific products such as machinery, ships and even cars. This paper aims to identify generic principles for the design of manufacturing systems delivering a wide range of products and services that meet the specific needs of individual customers. Baseline of this paper is the analysis of various industrial cases, consultancy as well as research projects in the broader field of customer driven manufacturing.
\end{abstract}

Keywords

Customer-driven Manufacturing, One-of-a-Kind Production, Mass Customisation.

\section{MANUFACTURING: A CUSTOMER NEEDS FULFILMENT PROCESS}

There is a long tradition in Europe in designing and manufacturing customer specific i.e. so called One-of a-kind products such as machinery systems, ships and even cars (Wortmann et al. 1997), (Hirsch, Thoben, 1992). One of a kind products in this respect are very often a mean to manufacture and/or provide products for (end -) consumers.

Mass customisation relates to the ability to provide customized products or services through flexible processes in high volumes and at reasonably low costs. The concept has emerged in the late 1980s and early 1990s and may be viewed as a natural follow up to processes that have become increasingly flexible and optimised regarding quality and costs.

However, whereas the concept of One-of-a-Kind Production (OKP) addresses mainly a customer in terms of a manufacturer and/or service provider, i.e. a buyer of capital or investment goods, the term Mass Customisation mainly addresses customers in terms of (end -) consumers. Although starting from different 
perspectives both approaches are aiming at a cost efficient customisation (and personalization) of the related products and services.

However, to understand the evolving concepts behind the term product, one has to look at the customer's demand from his requirements perspective and the key stages that fulfil the requirements. Based on the classical view on manufacturing systems a generic structure of a needs fulfilment process is depicted in Figure 1.

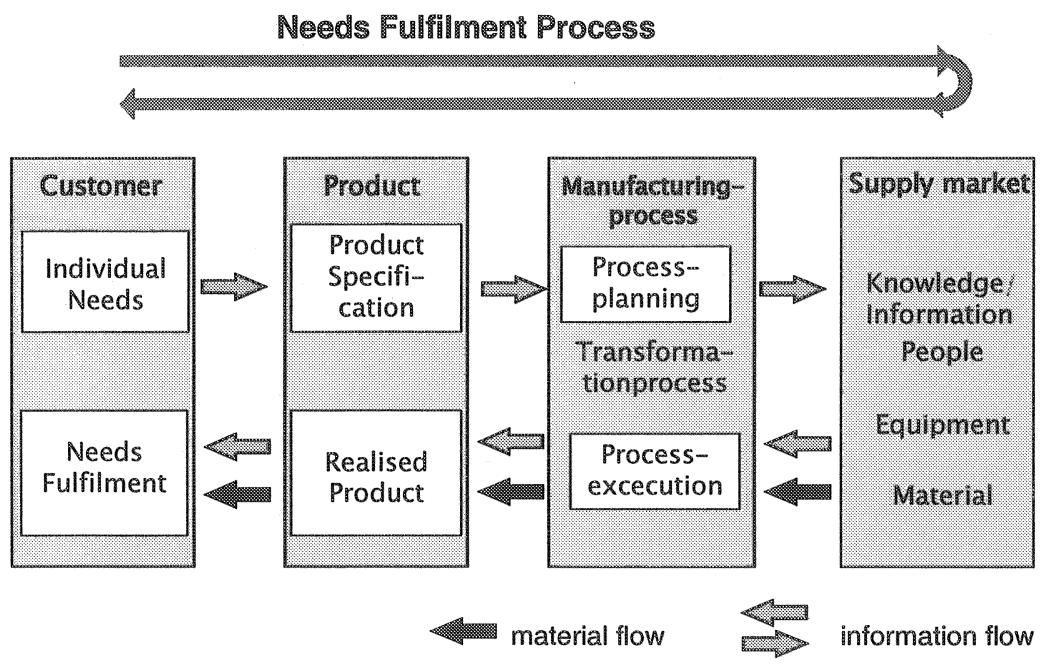

Figure 1 - Customer driven manufacturing as a "Needs Fulfilment Process"

One can gather from Figure 1 that beside the customer there are three stages in the needs fulfilment process:

Product: A product can be defined as an end item that will satisfy the customer's needs. Key features of a product include:

- It can consist of more than one physical entities,

- It can be a tangible entity that will be used or consumed by the customer. (In addition to any physical product, a software program is also considered to be a tangible product.)

- Product can also be intangible, such as information, knowledge, advice, consultancy services, etc.

- It can be a combination of tangible and intangible entities such as design services.

- A product has definable attributes that can be classified under time, cost, quality, functionality, etc.

a product also has distinct life-cycle phases - from initial concepts through to its final disposal.

Manufacturing Process (Transformation Process): It is a process (or processes) that is (are) used/consumed in the realisation of a product. Key attribute of realisation process include:

- It is carried out by one or more systems (enterprises) acting to achieve a common goal that is the realisation of a specified product that is required by a customer. 
- It will need infrastructures (e.g. buildings, utilities, etc.), resources (e.g. machinery, people, etc.) and materials for the realisation of the required product.

- It will behave as a customer to acquire the necessary resources and materials.

- It has distinct life-cycle phases with respect to the systems assembled to achieve realisation.

Supply Market (resource and infrastructures): The supply market i.e. (global available) resources, equipment, information/knowledge and people constitute an enterprise, or a group/network of enterprises that devote their resources and knowhow to actually produce the product.

\section{CODP IN CUSTOMIER-DRIVEN MANUFACTURING}

The manufacturing systems approach adopted by an organisation influences the manner in which that organisation conducts its manufacturing, planning and control activities. In stable and evolving dynamic markets the product has been classified based on the way its demand, from the manufacturer's perspective, is generated in other words, the point up to which a customer is involved in the final specification of the product. Based on the ratio between those parts of the manufacturing process which are driven by customer orders and those which are driven by forecasts according to Wortmann a manufacturing organisation's operation can be classified by introducing the notion of the Customer Order Decoupling Point (CODP) (Wortmann, 1997). The CODP refers to the point in the material flow from where customer-order-driven activities take place.

Make-to-stock (MTS) typifies the manufacture of products based on a familiar and relatively predictable demand mix, where product life cycles are reasonably long and stable. Assemble-to-order (ATO) organisations maintain a stock of semifinished products, so that following receipt of an order for a particular configuration, the relevant sub-assemblies can be assembled according to the actual demand. Make-to-order (MTO) organisations maintain a stock of standard components, so that following the receipt of an order for a particular design; the product is manufactured from these components. Interaction with the customer is extensive and is based on sales and engineering. The manufacture of machine tools and many capital goods are examples of this type of MTO manufacturing. Engineer-to-order (ETO) represents an extension of the MTO system, with the major difference being that the engineering design of the product is almost based on customer specifications. Customer interaction is greater and true one of a kind products are engineered to order.

End to End (ETE) represents an extension of the ETO approach. Starting point is the analysis of the needs of the customer, goal is not to provide a specific product but to achieve customer satisfaction.

Figure 3 indicates potential customer-driven activities in order processing in the capital goods industry. The customer's influence on the product can range from the definition of some delivery-related product specifications in advanced phases in the product life-cycle (e.g. packaging, transportation) to a modification of the ultimate 
functions of the product in the very early phases (e.g. customer-related product specifications).

\section{MASS CUSTOMISATION}

Despite the increasing attention $\mathrm{MC}$ has been receiving in practice as well as in literature, there is no common understanding about the term MC. Literature still provides a broad spectrum of definitions. Whereas some authors give a very broad and sometimes very general definition others provide more narrow and practical definitions. In a practical sense $\mathrm{MC}$ can be seen as an approach that uses information technology, flexible processes, and organizational structures to deliver a wide range of products and services that meet specific needs of individual customers (often defined by a series of options), at a cost near that of mass-produced items (Hart, 1995).

From an economic point of view, implementing the MC concept requests a careful determination of the range in which a product or service can be customized efficiently. The level or the levels of individualisation of the offered items seem to be critical for an appropriate definition. Pine e.g. suggests five stages of modular production: customized services (standard products are tailored by people in marketing and delivery before they reach customers), embedded customisation (standard products can be altered by customers during use), point-of-delivery customisation (additional custom work can be done at the point of sale), providing quick response (short time delivery of products), and modular production (standard components can be configured in a wide variety of products and services) (see Pine, 1993).

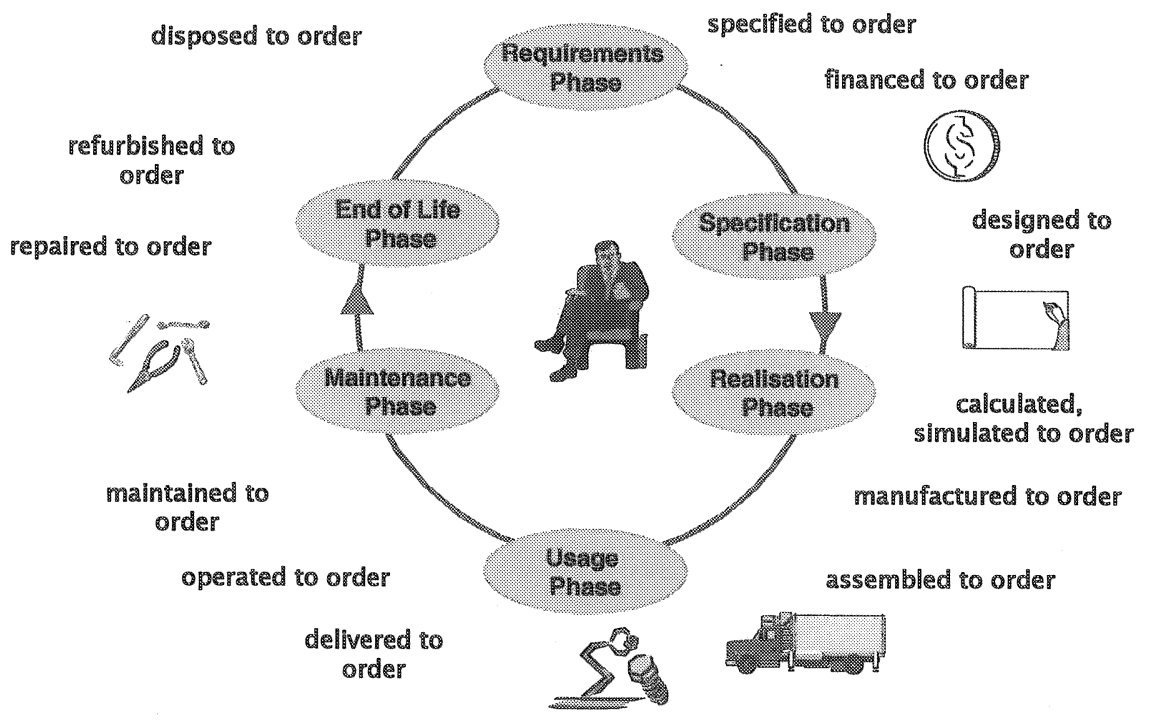

Figure 2 - Along its lifecycle a product can be: 


\section{Levels of customisation in MC}

Based on an analysis of existing frameworks to categorise the various levels of customisation of a product, Da Silveira et al. propose a set of eight generic levels of $\mathrm{MC}$, ranging from pure customisation (individually designed products) to pure standardization (see Table 1), (see Da Silveira, 2001).

Design as level 8 refers to collaborative product development, manufacturing and delivery of products according to individual customer preferences. The next level (Level 7: fabrication) refers to manufacturing of customer-tailored products based on predefined designs. Assembly as level 6 deals with the arranging of modular components into different configurations according to customer orders. On levels 5 and $4, \mathrm{MC}$ is achieved by simply adding custom work (e.g. Ikea furniture) or services to standard products (often at the point of delivery). In level 3, MC is provided by alternative approaches for distributing or packaging of products (e.g. different labels and/or box sizes according to specific market segments). In level two MC occurs only after delivery, through products that can be adapted to different functions or situations. Level 1 refers to pure standardization, a strategy that according to Da Silveira $e t$ al. can still be useful in many industrial segments.

Table 1 - Generic levels of Mass Customisation (according to Da Silveira et al., 2001)

\begin{tabular}{|c|c|c|c|c|}
\hline $\begin{array}{l}\text { MC Generic } \\
\text { levels }\end{array}$ & $\begin{array}{c}\text { MC } \\
\text { Approaches } \\
\text { (Gilmore/Pine, } \\
1997)\end{array}$ & $\begin{array}{l}\text { MC Strategies } \\
\text { (Lampel et al. } \\
1996)\end{array}$ & $\begin{array}{l}\text { Stages of MC } \\
\text { (Pine, 1993) }\end{array}$ & $\begin{array}{l}\text { Types of } \\
\text { customisation } \\
\text { (Spira, 1996) }\end{array}$ \\
\hline $\begin{array}{l}\text { Standardi } \\
\text { sation }\end{array}$ & $\ldots$ & $\begin{array}{c}\text { Pure } \\
\text { standardisation }\end{array}$ & $\ldots$ & $\cdots \cdots$ \\
\hline 2. Usage & Adaptive & $\ldots \ldots$ & $\begin{array}{c}\text { Embedded } \\
\text { customisation }\end{array}$ & $\ldots$. \\
\hline $\begin{array}{l}\text { 3. Package and } \\
\text { distribution }\end{array}$ & Cosmetic & $\begin{array}{c}\text { Segmented } \\
\text { standardisation }\end{array}$ & $\ldots . .$. & $\begin{array}{l}\text { Customising } \\
\text { packaging }\end{array}$ \\
\hline $\begin{array}{l}\text { 4. Additional } \\
\text { services }\end{array}$ & $\cdots$ & $\ldots$ & $\begin{array}{l}\text { Customised } \\
\text { services; } \\
\text { providg. quick } \\
\text { response }\end{array}$ & $\begin{array}{c}\text { Providing } \\
\text { additional } \\
\text { services }\end{array}$ \\
\hline $\begin{array}{l}\text { 5. Additional } \\
\text { custom work }\end{array}$ & $\cdots$ & $\ldots-$ & $\begin{array}{l}\text { Point of delivery } \\
\text { customisation }\end{array}$ & $\begin{array}{l}\text { Performing } \\
\text { additional } \\
\text { custom work }\end{array}$ \\
\hline 6. Assembly & $\ldots$ & $\begin{array}{c}\text { Customised } \\
\text { standardisation }\end{array}$ & $\begin{array}{l}\text { Modular } \\
\text { production }\end{array}$ & $\begin{array}{l}\text { Assembling } \\
\text { standard } \\
\text { components into } \\
\text { unique } \\
\text { configurations }\end{array}$ \\
\hline 7. Fabrication & $\cdots$ & $\begin{array}{c}\text { Tailored } \\
\text { customisation }\end{array}$ & $\ldots$ & $\ldots$ \\
\hline 8. Design & $\begin{array}{l}\text { Collaborative, } \\
\text { Transparent }\end{array}$ & $\begin{array}{c}\text { Pure } \\
\text { customisation }\end{array}$ & $\ldots$ & $\ldots-\cdots$ \\
\hline
\end{tabular}




\section{MASS CUSTOMISATION VS CDM}

Table 2 - Mass Customisation vs. Customer-driven Manufacturing

\begin{tabular}{|c|c|c|}
\hline $\begin{array}{c}\text { Complexity of } \\
\text { product }\end{array}$ & Low (usually commodities) & High (usually capital goods) \\
\hline $\begin{array}{c}\text { Level of } \\
\text { customisation of } \\
\text { product }\end{array}$ & $\begin{array}{c}\text { Low to medium (often restricted } \\
\text { to a limited variety of } \\
\text { configurations or product types) }\end{array}$ & $\begin{array}{c}\text { High to very high (What the } \\
\text { customer wants is what he will } \\
\text { get!) }\end{array}$ \\
\hline $\begin{array}{c}\text { lintegration of } \\
\text { customer into order } \\
\text { processing }\end{array}$ & Usually low & $\begin{array}{c}\text { Usually high (often fully } \\
\text { integrated) }\end{array}$ \\
\hline $\begin{array}{c}\text { Type of customer } \\
\text { addressed }\end{array}$ & Usually consumer & $\begin{array}{c}\text { Usually suppliers, service } \\
\text { providers, etc. }\end{array}$ \\
\hline
\end{tabular}

The concept of Mass Customisation (MC) as well as the concept of Customerdriven Manufacturing ( $\mathrm{CdM})$ originates from traditional manufacturing paradigms. Whereas the concept of Mass Customisation originates from the Mass Production Paradigm (MPP), the concept of Customer-driven Manufacturing originates from the One-of-a-Kind Production (OKP) Paradigm (Da Silveira, 2001), (Spira, 1996). However, today both underlying approaches i.e. MP as well as OKP are facing tremendous pressures: Customers are no more interested neither in buying standardised products nor in paying premium prices for customised products or even customised product features.

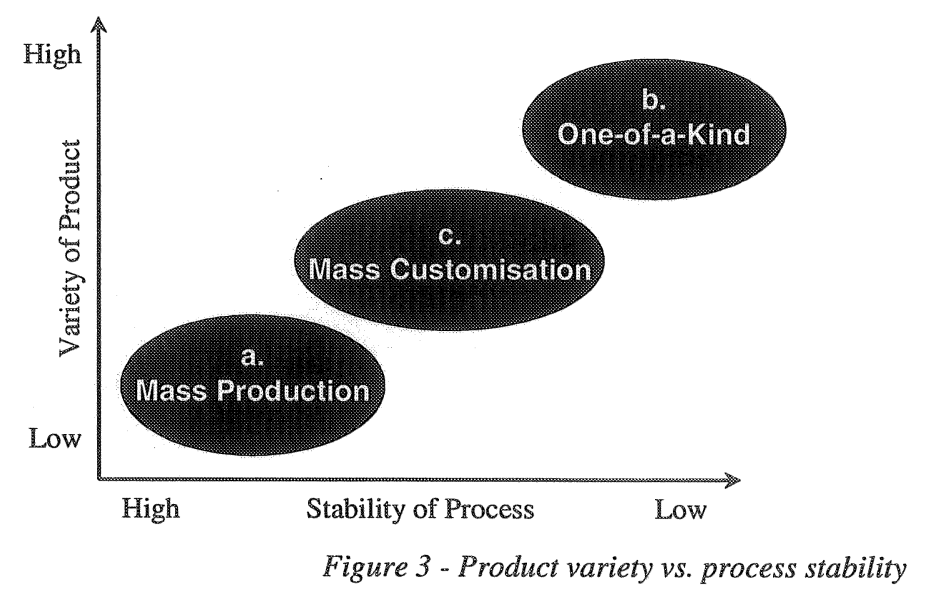

Figure 3 depicts a diagram considering product variety on the one axis and process stability on the other axis can be used to classify the various approaches. Whereas MP can be characterized by a high process stability (i.e. no changes, no modifications are needed during order processing) and a low product variety (in extreme cases there are no variants), the potential of OKP can be characterised by high product variety and low process stability (product specifications as well as process specifications are changing from order to order), (see Figure $3 \mathrm{a}-\mathrm{b}$ ). 
As the stability and the smooth operation of a production process is a prerequisite for cost efficiency the MC approach tries to keep the stability of the process but to increase the variety of products (see Figure $3 \mathrm{c}$ ). To pursue these seemingly excluding goals has become possible, since modern manufacturing and information technologies offer the ability to companies to deliver a certain range of products and services that meet even the needs of individual customers at a cost near that of mass-produced items.

Whereas the $\mathrm{MC}$ concept mainly addresses the customer in terms of a consumer the concept of Customer-driven Manufacturing addresses mainly the customer in terms of a manufacturer and/or service provider, i.e. the capital goods industry. Originating from customized production approaches $\mathrm{CdM}$ is aiming at an increase of process stability without a decrease in the variety of the products to be offered to the customers.

\section{Common objectives}

Starting from different perspectives both approaches do have a common objective in cost efficient customisation (and personalization) of products and services.

Using the concept of the customer order decoupling point (CODP) the different starting points of both approaches become obvious (see Figure 4). As discussed above in Table 1 the main focus of MC so far is on ATO (Assemble-to-order) and MTO (Make-to-order). The Engineer-to-order (ETO) approach so far is not realised in practise or-if implemented-restricted to the customer driven variation of single and predefined product features.

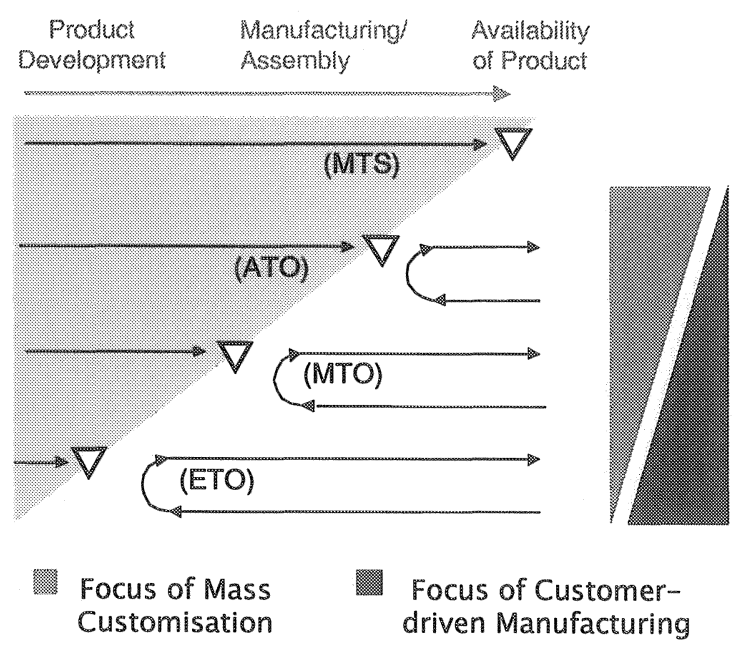

Figure 4 - Classifying MC and CdM by using the customer order decoupling point (CODP)

Figure 5 depicts a set steps or even changes to undergo for a mass-producer as well as for a one-of-a-kind manufacturer to become a mass-customising company. By increasing the customer focus through the implementation of the proposed 
changes a mass producer has to take care of his cost-advantages. Losing the costadvantages and failing in achieving an increased customer focus leads to a critical situation for a company. By improving the cost focus a one-of-a-kind producer has to take care of his competitive advantages based on his customer focus. To lose the competitive advantage based on the customised offerings and to fail in achieving cost-advantages leads to a critical situation for this company as well. However in both cases a careful change management process is crucial for a success development of the company.

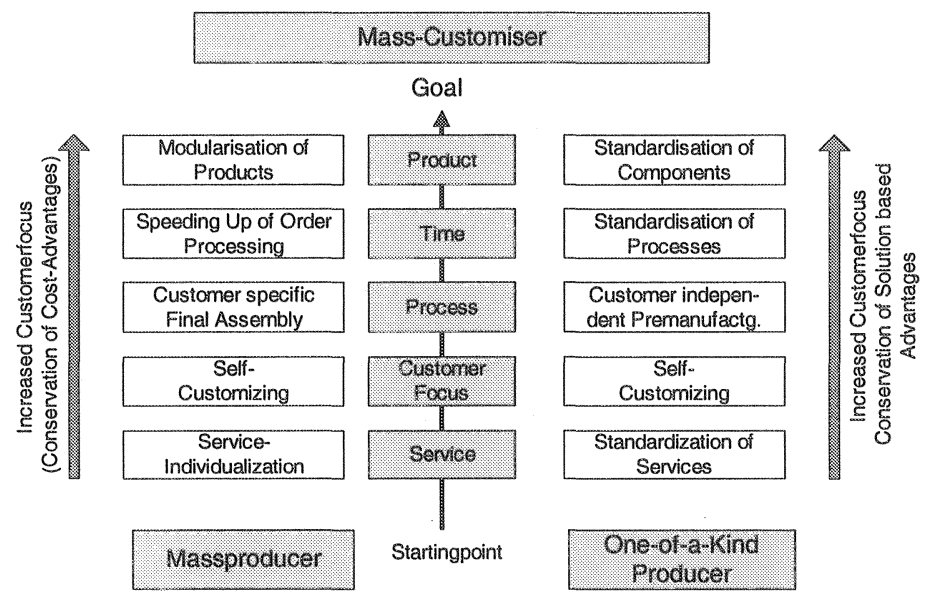

Figure 5 - Two starting points, one ultimate goal: From Mass Production and One-of-a Kind Production to Mass Customisation (based on Reiß et al. [14])

Da Silveira et al. identified six success factors for Mass Customisation most commonly emphasized in literature (Da Silveira et al., 2001):

1. Customer demand for variety and customisation must exist.

2. Market conditions must be appropriate

3. Value chain should be ready.

4. Manufacturing and information technology must be available.

5. Products should be customisable (Products must be modularised, versatile and constantly renewed).

6. Knowledge must be shared across the value chain.

As the successful implementation of MC relies on these success factors $\mathrm{MC}$ cannot be seen as every company's best strategy. To summarise, a successful implementation of $\mathrm{MC}$ involves major aspects of operations including product configuration, value chain network, process and information technology, and the development of a knowledge-based organizational structure.

\section{Principles for manufacturing systems design}

Customer-driven manufacturing strategies in general intend to cover the various levels of individualisation of products and processes. However, what are the basic 
principles companies have to apply or to follow to design efficient, customer (needs) driven manufacturing systems. In other words, what are the basic principles in designing manufacturing systems to deliver a wide range of products and services that meet the specific needs of individual customers.

Table 3 - Selection of design principles to be applied in Customer driven Manufacturing systems design

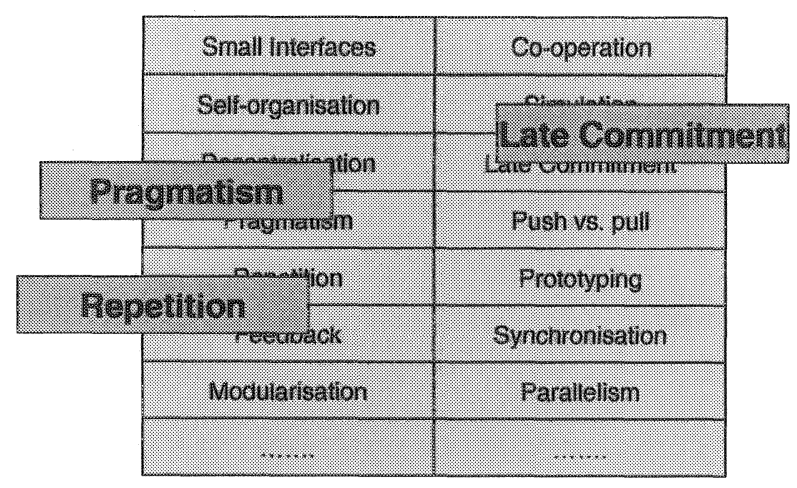

Principles for manufacturing systems design are general rules or guidelines that a company should try to obey in designing efficient customer-driven manufacturing systems. However, system design principles for customer-driven manufacturing systems are rules that show how customer driven-manufacturing might be put into practice.

In a study various industrial cases, industrial, consultancy as well as research projects in the broader field of customer driven manufacturing (including software development) have been analyzed and a set of design principles for the appropriate design of customer driven manufacturing systems have been identified by the author (Thoben, 2001). Table 4 shows a selection of principles identified.

Starting point for this analysis was the specification of the generic dimensions of a customer specific order. According to decision theory various strategies are applicable in dealing with the dimensions of such problems. Problems can be anticipated, eliminated, ignored, minimized or controlled, etc. (Figure 5).

From a problem oriented perspective order processing in customer driven manufacturing can be seen as a problem solving process conducted by a company. Analysing the various facets of this type of "problems" a set of so-called problem dimensions can be defined. Accordingly a customer order can be characterized by a number of dimensions such as:

Cost-criticality

Time-criticality

Novelty

Uniqueness

Complexity

* Non-transparency

- Initial Dynamics (Momentum)

Uncertainty of Goal 


\begin{tabular}{|c|c|c|c|}
\hline \multirow{2}{*}{ Procedure: } & \multirow[b]{2}{*}{ Descripition } & \multicolumn{2}{|c|}{ Slarus of probiem } \\
\hline & & $\begin{array}{l}\text { Noryat } \\
\text { ariest }\end{array}$ & ant ro be \\
\hline $\begin{array}{c}\text { To } \\
\text { anticipate }\end{array}$ & $\begin{array}{l}\text { To prevent the } \\
\text { evolution of a problem }\end{array}$ & & \\
\hline $\begin{array}{l}\text { To } \\
\text { eliminate }\end{array}$ & $\begin{array}{c}\text { Complete removal of a } \\
\text { problem which has } \\
\text { been arisen }\end{array}$ & & \\
\hline $\begin{array}{l}\text { To } \\
\text { minimise }\end{array}$ & $\begin{array}{l}\text { To reduce an existing } \\
\text { problem to the lowesr } \\
\text { degree possible }\end{array}$ & & \\
\hline $\begin{array}{l}\text { To } \\
\text { ignore }\end{array}$ & $\begin{array}{l}\text { Meaningful neglect of } \\
\text { an existing problem }\end{array}$ & & \\
\hline $\begin{array}{l}\text { To } \\
\text { control }\end{array}$ & $\begin{array}{c}\text { Acceptance of a } \\
\text { problem and systematic } \\
\text { solution approach }\end{array}$ & & \\
\hline
\end{tabular}

Figure 5 - Problem solution strategies

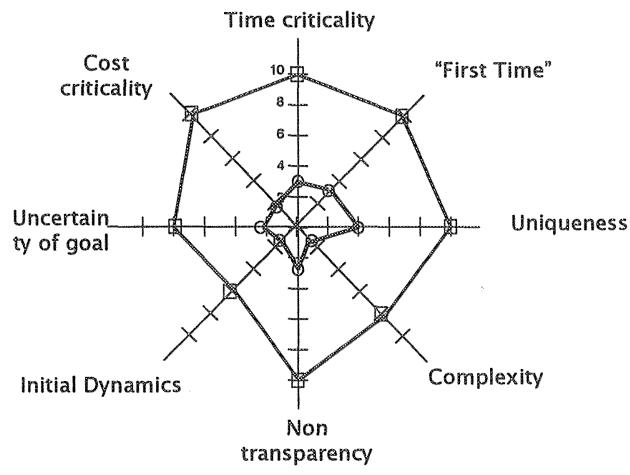

Figure 6-Characterizing cases in Customer-driven Manufacturing

A template to qualitatively characterize the concept as well as the potentials of the design principles in a standardized way has been developed. This template includes sections like "Relationships with other principles", "Potential to solve a problem", "Potential for application" (i.e. application domain), etc. As the principles have been identified by analysing real life cases, examples, etc. they are not independent of each other. Accordingly one principle can prepare, enable, support or even hinder the application of another or various other principles. However no research has been done so far to classify or to measure the relationship in a quantitative manner. Figure 7 shows the template to systematically characterize the principle "Late Commitment". 


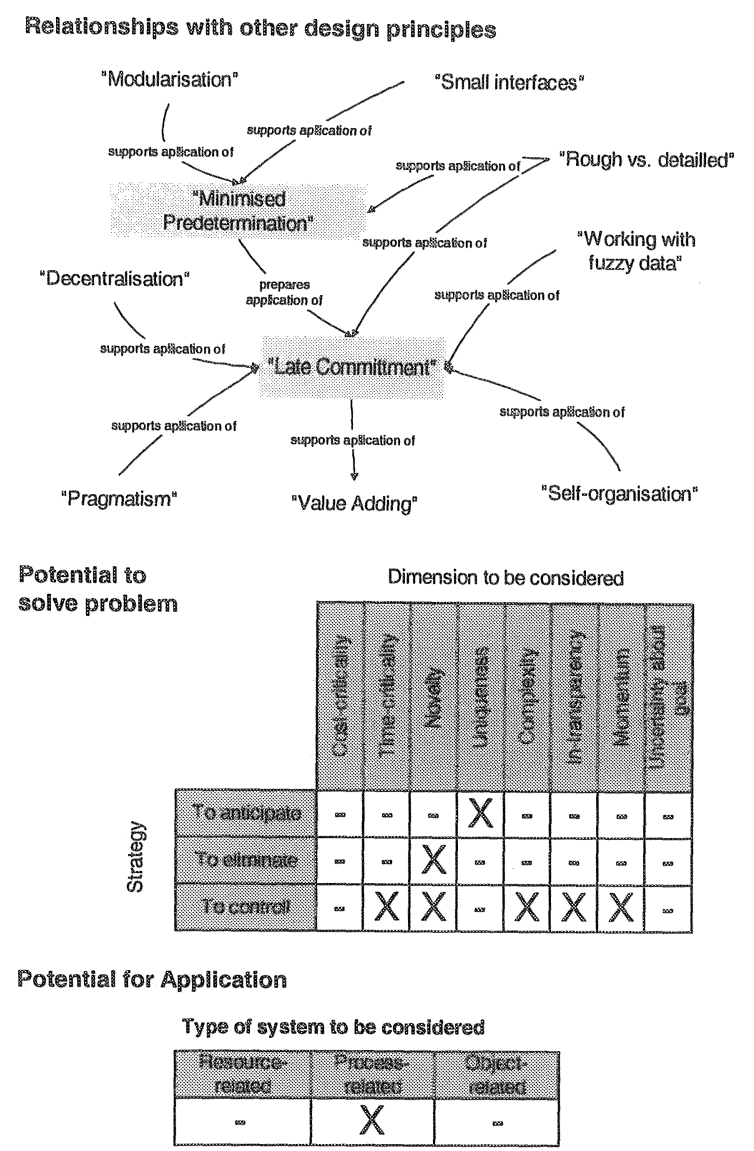

Figure 7 - Characterisation of design principles in CdM (example) (Thoben, 2002)

Some of the principles identified in the study are of generic nature, whereas others are very specific. Generic principles might be applied to the different organisational levels (strategic, tactical and operational) within a company, whereas the field of other principles is limited.

First steps in analysing industrial cases, literature and research projects related to $\mathrm{MC}$ have shown that design principles are applied here as well. However, as MC and $\mathrm{CdM}$ originates from different manufacturing paradigms (see above), there are many differences as well.

"Late differentiation" e.g. is used as one major principle in MC. Applying this principle allows companies to have standard processes until the point of differentiation, very often a prerequisite for cost efficient process design in MC. Apart from the principle "Late differentiation" (synonym in CdM is "Late individualisation") in CdM the principle "Late Commitment" is used quiet frequently.

This principle again is well known in decision theory: „,Make safe decisions first / dangerous decisions very late". Even in product data modelling a similar principle 
is being applied: „Early Binding" vs. „Late Binding“. De Vin proposed to apply the strategy called "Design by least commitment" in such cases where designers have to take decisions in very unstable environments (De Vin, L.J., 1998). Similar proposals have been made as well by (Marri et al. 1998) and by (Knackfuß, 1992) for decision making in process planning.

\section{CONCLUSIONS}

Both approaches, Mass Customisation (MC) as well as Customer-driven Manufacturing (CdM) theoretically intend to cover the various levels of individualization of products. Whereas the MC concept originates from the Mass Production Paradigm (MPP), the CdM concept originates from the One-of-a-Kind Production (OKP) Paradigm. Accordingly the MC concept mainly addresses the customer in terms of a consumer and the CdM concept addresses mainly the customer in terms of a manufacturer and/or service provider, i.e. the capital goods industry. However, it can be stated that the more complex the products, the higher the level of customisation of the product and the more intensive the integration of the customer into the order processing the applications of MC seems to be limited. At the same time the the CdM concept seems to be weak when the objective is to deliver customised products at a cost near that of mass-produced items.

To summarize, as it is very often the case both approaches, MC and CdM, do have strong as well as weak points. Identifying and applying generic design principles for manufacturing systems providing customized products seems to be a promising approach.

\section{REFERENCES}

[1] Hirsch, B.E., Thoben, K.-D., 1997, Why Customer-driven Manufacturing, in (Wortmann, J.C.; Muntslag, D.R.; Timmermanns, P.J.M., 1997) 33 - 44.

[2] Pine, J., 1993, Mass customizing products and services, Planning Review 21 (4) 6-13.

[3] Thoben, K.-D., 2001, Kundenspezifische Produktion - Anforderungen, Prinzipien, Methoden und Werkzeuge; Habilitationsschrift, University of Bremen, Germany, (To be published in 2002).

[4] Wortmann, J.C.; Muntslag, D.R.; Timmermanns, P.J.M. (Eds.), 1997, Customer-driven Manufacturing; Chapman \& Hall, London, Weinheim, New York.

[5] Da Silveira, G., Borenstein, D., Fogliatto, F.S., 2001, Mass Customisation: Literature review and research directions, Int. J. Production Economics 72/1 - 13.

[6] Pine, J., Victor, B., Boyton, A., 1993, Making mass customisation work, Harvard Business Review 71 (5) $108-111$.

17] Hart, C., 1995, Mass customisation: Conceptual underpinnings, opportunities and limits, International Journal of Service Industry Management 6 (2) $36-45$.

[8] Gilmore, J., Pine, J., 1997, The four faces of mass customisation, Harvard Business Review 75 (1) $91-101$.

[9] Hart, C., 1996, Made to order, Marketing 5 (2) $10-23$.

[10] Hirsch, B.E., Thoben, K.D., (Eds.), 1992, One of a Kind Production: New Approaches, North-Holland, Amsterdam. 
[11] Wortmann, J.C., 1997, A typology of customer-driven manufacturing, in (Wortmann, et al., 1997), Customer-driven Manufacturing; Chapman \& Hall, London, Weinheim, New York], 59-73.

[12] Lampel, J., Mintzberg, H., 1996, Customizing Customisation, Sloan Management Review 38, $21-30$.

[13] Spira, J., 1996, Mass customisation through training at Lutron Electronics, Computers in Industry 30 (3) $171-174$.

[14] Reiß, M., Beck, T.C., 1994, Fertigung jenseits des Kosten-Flexibilitäts-Dilemmas. Mass Customisation als Strategiekonzept für Massenfertiger und Einzelfertiger, VDI-Z, 136 (11/12), $28-30$.

[15] De Vin, L.J., 1998, Co-operation between Manufacturing Functions in Sheet Metal Part Manufacturing, in: Martensson, N; Mackay, R.; Björgvinsson, (Eds.): Changing the Ways We Work; Advances in Design and Manufacturing, 8425 - 431

[16] Marri, H.B., Gunasekaran, A., Grieve, R.J., 1998, Computer Aided Process Planning: A State of the Art; International Journal of Advanced Manufacturing Technology 14, pp $261-268$.

[17] Knackfuß, P., 1992, Ein Konzept zur merkmalsgestützten Konstruktion, Arbeitsvorbereitung und Fertigungssteuerung bei der Herstellung von Blechteilen, Dissertation, Universität Bremen, 1992. 